\title{
Mathematical model validation of conventional solar still under Egyptian Conditions
}

\section{Aly E. Montaser $1^{\# 1}$, Mohamed A. Teamah $2^{\# 2}$,Mohamed M. Khairt Dawood $3^{\# 3}$,} Ali I. Shehata $4^{\# 4}$

\#1 Department of Mechanical Engineering, College of Engineering and Technology, Arab Academy for Science and Technology and Maritime Transport, Abu-Quir, Alexandria, Egypt, +201285246472, eng.alimontaser@hotmail.com

\#2 Department of Mechanical Engineering, College of Engineering and Technology, Arab Academy for Science and Technology and Maritime Transport, Abu-Quir, Alexandria, Egypt, +201003969521,mteamah@yahoo.com

\#3 Faculty of Engineering, Suez Canal University, Ismailia, Egypt, +201099558136, Kairat4975@yahoo.com

\#4 Department of Mechanical Engineering, College of Engineering and Technology, Arab

Academy for Science and Technology and Maritime Transport, Abu-Quir, Alexandria, Egypt,+201223860234, alii9457@gmail.com

\section{ABSTRACT}

In this paper, mathematical model for the conventional solar still was established. Numerical solution for the model has been performed using MATLAB software. The main objective of this research is to compare the hourly distillate produced from the conventional solar still resulting from the present numerical solution with the measured hourly distillate of other researcher in order to validate the mathematical model. The results show good agreement when comparing the numerical solution results and the experimental results on 25 May 2013 for operating hours from 9:00 a.m. to 17:00 p.m. in Kafrelsheikh, Egypt.

Key words: Distillation, hourly distillate, numerical solution, Solar still, validation.

Corresponding Author: Aly E. Montaser

\section{INTRODUCTION}

Water treatment by desalination is the oldest method for getting pure water. Different technologies for desalination have been developed through the years such as reverse osmosis, vapor compression and electrolysis. These technologies are working by using fossil fuels as a source of energy to produce pure water [1].But there are some disadvantages for using Fossil fuels, because its resources have fixed amount and they are considered as non-renewable resources. Consequently, there will be a lack in fossil fuels. Also, using of fossil fuels contribute in environmental pollution and global warming. This highlighted the importance to alternate the high cost energy source with renewable energies [2]. Solving the fossil fuels problems can be done by using renewable energy to be an energy source for water 
desalination like geothermal, biomass, wind or solar energy [3]. The best solution for potable water supply for small and isolated societies, where the natural supply of fresh water is not enough or not pure and the sunshine is plentiful, is the distillation using solar energy [4]. The man-made solar still is working on the hydrological cycle principle. The basic components of the solar still include inclined glass cover, insulation, basin, distillate tank [5]. The solar still basin is filled with contaminated or undrinkable water, then the solar radiation is crossed the inclined glass cover resultant in heating and evaporation of the water inside the basin. The cleaned water vapor rises upward and condenses on the inclined glass cover internal surface. The contaminations are left in the still basin and the condensate water moves down to the still lower side and collected in a distilled water tank [1].

A mathematical model was used to conclude of the influence of different operational, design and climatic parameters on the productivity of a simple solar still. From results, it can be noticed that increased the ambient air temperatures $10^{\circ} \mathrm{C}$ raised the productivity by $8.2 \%$ [6].

Numerically investigation was done to evaluate the performance of the passive and the active solar stills monthly for various climatic conditions in India. It was concluded that the yearly production rate for both active and passive solar stills highly depends on the depth of water and the inclination of the collector and the condensing cover. Also, for the active solar still the yearly yield for a specific water depth rises linearly with the area of the collector. The results showed that the maximum annual production rate reached when the condensing glass cover inclination had the same value of the location's latitude. In addition, it was found that the best inclination for the flat plate collector is $28.58^{\circ}$ and $18.58^{\circ}$ for the glass cover for the climatic conditions in New Delhi [7].

An extensive review was carried out for some of numerical and experimental studies for solar stills basic types. Many researches were discussed about the parameter of the inlet water temperature to the solar still. It was found that the evaporation rate is proportional to water temperature free surface area only. Accordingly, it could be increase the water surface area by using baffle suspended absorber plates [8].

The effect of adding a compression heat pump to a simple solar still was investigated numerically. Comparison was done between the performance of the proposed model and the conventional solar still under the same climatic condition. The results showed that adding a compression heat pump could increase the productivity by $75 \%$ compared to the conventional solar still. Also, the effect of other parameters on the yield of the still was studied. It is concluded that that daily yield was inversely proportional to the thickness of the water in the solar basin. In addition, the insulation effect was marginal [9].

The objective of this study is to solve the conventional solar still components governing equations numerically by MATLAB and compare the hourly distillate produced from the present model with experimental results of other literature [10] in order to validate the present mathematical model.

\section{Solar still thermal models}

A mathematical model was established to simulate the performance of the conventional solar still. For simplifications, the following assumptions have been carried out:

1. There is no vapor leakage from the solar still.

2. The temperature gradient in the solar still basin, saline water and glass cover is negligible.

3. Thermal resistance of the basin and glass cover is neglected.

4. The side heat loss from the solar still is neglected.

5. The depth of the saline water in the solar still is kept constant.

6. The heat capacity of the insulating material is negligible. 
7. The side Area is very small compared to the basin Area.

8. The solar still is operating in a transition mode.

9. The amount of evaporation of water is equal to the amount of water condensed.

Energy balance equations for the glass cover, the water in the solar still and basin plate in the bottom will be written as below:

Energy balance for the glass cover[11]:

Energy balance for the water[11]:

$$
\begin{aligned}
\mathrm{I}_{\mathrm{T}}(\mathrm{t}) \mathrm{A}_{\mathrm{g}} \alpha_{\mathrm{g}}+\mathrm{Q}_{\text {conv,w-g }}+\mathrm{Q}_{\text {rad,w-g }}+Q_{\text {evap,w-g }} \\
=\mathrm{m}_{\mathrm{g}} \mathrm{C}_{\mathrm{pg}} \frac{\mathrm{dT}_{\mathrm{g}}}{\mathrm{dt}}+\mathrm{Q}_{\text {rad,g-s }}+Q_{\text {conv,g-a }}
\end{aligned}
$$

$$
\begin{aligned}
\mathrm{I}_{\mathrm{T}}(\mathrm{t}) \mathrm{A}_{\mathrm{w}} \alpha_{\mathrm{w}}+ & Q_{\text {conv,b-w }} \\
& =\mathrm{m}_{\mathrm{w}} \mathrm{C}_{\mathrm{pw}} \frac{\mathrm{dT}_{\mathrm{w}}}{\mathrm{dt}}+\mathrm{Q}_{\text {conv }, \mathrm{w}-\mathrm{g}}+\mathrm{Q}_{\mathrm{rad}, \mathrm{w}-\mathrm{g}}+\mathrm{Q}_{\text {evap }, \mathrm{w}-\mathrm{g}}+\mathrm{Q}_{\mathrm{fw}}
\end{aligned}
$$

Energy balance for the basin plate[11]:

$$
I_{T}(t) A_{b} \alpha_{b}=m_{b} C_{p b} \frac{d T_{b}}{d t}+Q_{\text {conv, } b-w}+Q_{\text {loss }}
$$

Where $Q_{\text {conv,w-g }}, Q_{\text {rad,w-g }}, Q_{\text {evap,w-g }}, Q_{\text {conv,b-w }}$ are the convection heat transfer within the solar still from water mass and glass cover, the radiation heat transfer within the solar still from water mass and glass cover, the evaporation heat transfer within the solar still from water mass and glass cover and the convection heat transfer between basin liner and water mass respectively [12]:

$$
\begin{aligned}
& \mathrm{Q}_{\text {conv }, \mathrm{w}-\mathrm{g}}=\mathrm{h}_{\mathrm{c}, \mathrm{w}-\mathrm{g}} \mathrm{A}_{\mathrm{w}}\left(\mathrm{T}_{\mathrm{w}}-\mathrm{T}_{\mathrm{g}}\right) \\
& \mathrm{Q}_{\text {rad,w-g }}=\mathrm{h}_{\mathrm{r}, \mathrm{w}-\mathrm{g}} \mathrm{A}_{\mathrm{w}}\left(\mathrm{T}_{\mathrm{w}}-\mathrm{T}_{\mathrm{g}}\right) \\
& \mathrm{Q}_{\text {evap }, \mathrm{w}-\mathrm{g}}=\mathrm{h}_{\mathrm{e}, \mathrm{w}-\mathrm{g}} \mathrm{A}_{\mathrm{w}}\left(\mathrm{T}_{\mathrm{w}}-\mathrm{T}_{\mathrm{g}}\right) \\
& \mathrm{Q}_{\text {conv }, \mathrm{b}-\mathrm{w}}=\mathrm{h}_{\mathrm{c}, \mathrm{b}-\mathrm{w}} \mathrm{A}_{\mathrm{b}}\left(\mathrm{T}_{\mathrm{b}}-\mathrm{T}_{\mathrm{w}}\right)
\end{aligned}
$$

$h_{c, w-g}, h_{r, w-g}, h_{e, w-g}$ and $h_{c, b-w}$ could be found in the literature [12].

$\mathrm{Q}_{\text {rad,g-s }}$ is the radiation heat transfer between glass cover and sky [13]:

$$
\mathrm{Q}_{\mathrm{rad}, \mathrm{g}-\mathrm{s}}=\mathrm{h}_{\mathrm{r}, \mathrm{g}-\mathrm{s}} \mathrm{A}_{\mathrm{g}}\left(\mathrm{T}_{\mathrm{g}}-\mathrm{T}_{\mathrm{a}}\right)
$$

$\mathrm{h}_{\mathrm{r}, \mathrm{g}-\mathrm{s}}$ could be found in the literature [13].

$\mathrm{Q}_{\mathrm{conv}, \mathrm{g}-\mathrm{a}}, \mathrm{Q}_{\mathrm{fw}}$ are the convection heat transfer between glass cover and ambient air, the heat taken by the replaced water respectively[14]:

$$
\begin{gathered}
\mathrm{Q}_{\text {conv,g-a }}=\mathrm{h}_{\mathrm{c}, \mathrm{g}-\mathrm{a}} \mathrm{A}_{\mathrm{g}}\left(\mathrm{T}_{\mathrm{g}}-\mathrm{T}_{\mathrm{a}}\right) \\
\mathrm{Q}_{\mathrm{fw}}=\mathrm{m}_{\mathrm{e}} \mathrm{C}_{\mathrm{pw}}\left(\mathrm{T}_{\mathrm{w}}-\mathrm{T}_{\mathrm{a}}\right)
\end{gathered}
$$

$\mathrm{h}_{\mathrm{c}, \mathrm{g}-\mathrm{a}}$ could be found in the literature [15].

$\mathrm{Q}_{\text {loss }}$ is the conduction heat transfer between basin liner and atmosphere [15]: 


$$
\mathrm{Q}_{\text {loss }}=\mathrm{h}_{\mathrm{b}} \mathrm{A}_{\mathrm{b}}\left(\mathrm{T}_{\mathrm{b}}-\mathrm{T}_{\mathrm{a}}\right)
$$

The instantaneous water production out of the still is calculated from[14]:

$$
\mathrm{m}_{\mathrm{e}}=\mathrm{Q}_{\text {evap }, \mathrm{w}-\mathrm{g}} / \mathrm{h}_{\mathrm{fg}}
$$

Also, the total accumulated production out of the still is given by[14]:

$$
\begin{gathered}
\mathrm{m}_{\text {total }}=\sum \mathrm{m}_{\mathrm{e}}(\mathrm{t}) \Delta \mathrm{t} \\
\mathrm{m}_{\text {total }}=\sum \mathrm{Q}_{\text {evap }, \mathrm{w}-\mathrm{g}}(\mathrm{t}) \Delta \mathrm{t} / \mathrm{h}_{\mathrm{fg}}
\end{gathered}
$$

\section{Numerical solution}

A mathematical model was developed by a computer program (MATLAB software) in order to evaluate the conventional solar still performance and calculate the hourly distillate produced from the solar still. The computer program is used to solve numerically the energy balance equations for the conventional solar still components. The solar still technical specification can be found in the literature [10]. The present MATLAB code can solve the energy balance equations to evaluate the temperatures of the glass cover $T_{g}$, saline water $T_{w}$ and basin liner $\mathrm{T}_{\mathrm{b}}$ every time. The Fourth order Runge-Kutta (RK4) method is the method that is used for the numerical solution. It is used to solve a system of nonlinear ordinary differential equations from equation (1) to equation (14) to get $\mathrm{T}_{\mathrm{g}}, \mathrm{T}_{\mathrm{w}}$ and $\mathrm{T}_{\mathrm{b}}$ and the instantaneous water production produced from the solar still. Numerical solution starting at 9:00 a.m. assuming that the initial temperatures at 9:00 a.m. for saline water, basin liner \& glass cover to be approximately the same as ambient temperature. Then, the internal and external heat transfer coefficients will be calculated depending on the initial assumed temperatures. Then, the equations will be solved numerically to get new temperatures that will be used again as initial temperatures to get the new heat transfer coefficients and the process will be repeated for additional time step until 17:00 p.m. of the same day. Finally, after getting the temperature for each components of the solar still, the amount of the accumulated condensed water will be calculated hourly. The time step used in the present numerical solution (1 second).

\section{Model validation}

In order to validate the numerical solution of the present MATLAB code, comparisons are tested between the resultant hourly distillate from the numerical solution and the hourly distillate measured from the experimental investigation of the researcher[10]. The validation on 25 May 2015 compares the hourly distillate resultant from the numerical solution with the hourly distillate measured from the experimental investigation[10]. The comparison between the numerical solution results from the present code and the measured values from the experimental investigation is presented in Figures 1. The relative error did not exceed $20 \%$. This divergence in hourly distillate between the present model and the measured values might be exist due to the meteorological parameters (ambient temperature and speed of the wind) .So, Figures 1 show good agreement with[10]. 


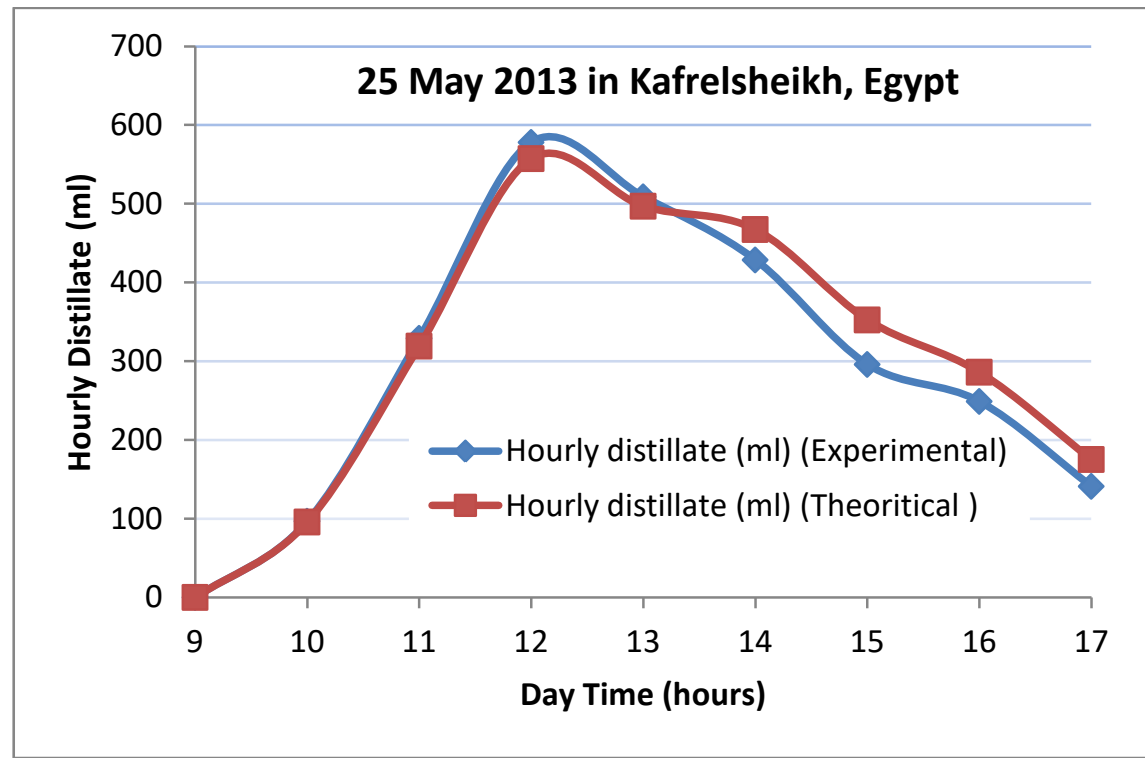

Fig 1: Variation of the Hourly Distillate with operating hours from 9:00 a.m. to 17:00 p.m. (Numerical solution results and experimental results) for the conventional solar still under climatic conditions of Kafrelsheikh, Egypt on 25 May 2013.

\section{NOMENCLATURE}

Symbols

$$
A_{b}
$$

$\mathrm{A}_{\mathrm{g}}$

$\mathrm{A}_{\mathrm{w}}$

$\mathrm{C}_{\mathrm{pb}}$

$\mathrm{C}_{\mathrm{pg}}$

$\mathrm{C}_{\mathrm{pw}}$

$\mathrm{h}_{\mathrm{b}}$

$\mathrm{h}_{\mathrm{c}, \mathrm{b}-\mathrm{w}}$

$\mathrm{h}_{\mathrm{c}, \mathrm{g}-\mathrm{a}}$

$\mathrm{h}_{\mathrm{c}, \mathrm{w}-\mathrm{g}}$

$\mathrm{h}_{\mathrm{e}, \mathrm{w}-\mathrm{g}}$

$\mathrm{h}_{\mathrm{fg}}$

$\mathrm{h}_{\mathrm{r}, \mathrm{g}-\mathrm{s}}$

$\mathrm{h}_{\mathrm{r}, \mathrm{w}-\mathrm{g}}$

\section{Nomenclatures}

Surface Area of solar still basin liner

Surface area of solar still glass

Surface Area of water mass inside the solar still

Specific heat capacity of the basin liner

Specific heat capacity of the glass cover

Specific heat capacity of the water mass

Heat transfer coefficient between basin liner and the atmosphere via the insulation

Convective heat transfer coefficient between basin liner and water mass

Convective heat transfer coefficient between glass cover and ambient air

Convective heat transfer coefficient from water mass and glass cover

Evaporative heat transfer coefficient from water mass and glass cover

The latent heat of vaporization

Radiative heat transfer coefficient between glass cover and sky

Radiation heat transfer coefficient from water mass and glass cover
Units

$\mathrm{m}^{2}$

$\mathrm{m}^{2}$

$\mathrm{m}^{2}$

$(\mathrm{J} / \mathrm{kg} \quad \mathrm{K})$

$(\mathrm{J} / \mathrm{kg} \mathrm{K})$

$(\mathrm{J} / \mathrm{kg} \mathrm{K})$

$\mathrm{W} / \mathrm{m}^{2} \mathrm{~K}$

$\mathrm{W} / \mathrm{m}^{2} \mathrm{~K}$

$\mathrm{W} / \mathrm{m}^{2} \mathrm{~K}$

$\mathrm{W} / \mathrm{m}^{2} \mathrm{~K}$

$\mathrm{W} / \mathrm{m}^{2} \mathrm{~K}$

$\mathrm{J} / \mathrm{kg}$

$\mathrm{W} / \mathrm{m}^{2} \mathrm{~K}$

$\mathrm{W} / \mathrm{m}^{2} \mathrm{~K}$ 


\begin{tabular}{|c|c|c|}
\hline $\mathrm{I}_{\mathrm{T}}(\mathrm{t})$ & $\begin{array}{l}\text { The total solar radiation on the inclined glass } \\
\text { cover of the solar still }\end{array}$ & $\mathrm{w} / \mathrm{m}^{2}$ \\
\hline $\mathrm{m}_{\mathrm{b}}$ & Basin liner mass & $\mathrm{kg} / \mathrm{s}$ \\
\hline $\mathrm{m}_{\mathrm{e}}$ & $\begin{array}{l}\text { The instantaneous water production out of the } \\
\text { solar still }\end{array}$ & $\mathrm{kg} / \mathrm{s}$ \\
\hline $\mathrm{m}_{\mathrm{g}}$ & Glass cover mass & $\mathrm{kg}$ \\
\hline $\mathrm{m}_{\text {total }}$ & $\begin{array}{l}\text { The total accumulated production out of the } \\
\text { solar still }\end{array}$ & $\mathrm{kg}$ \\
\hline $\mathrm{m}_{\mathrm{w}}$ & Water mass & $\mathrm{kg}$ \\
\hline $\mathrm{Q}_{\mathrm{conv}, \mathrm{b}-\mathrm{w}}$ & $\begin{array}{l}\text { Convection heat transfer between basin liner } \\
\text { and water mass }\end{array}$ & W \\
\hline $\mathrm{Q}_{\mathrm{conv}, \mathrm{g}-\mathrm{a}}$ & $\begin{array}{c}\text { Convection heat transfer between glass cover } \\
\text { and ambient air }\end{array}$ & W \\
\hline $\mathrm{Q}_{\text {Conv,w-g }}$ & $\begin{array}{l}\text { Convection heat transfer within the solar still } \\
\text { from water mass and glass cover }\end{array}$ & W \\
\hline
\end{tabular}

\section{NOMENCLATURE (Cont'd)}

Symbols
Qevap,w-g
$\mathrm{Q}_{\mathrm{fw}}$
$\mathrm{Q}_{\text {loss }}$
$\mathrm{Q}_{\text {rad,g-s }}$
$\mathrm{Q}_{\mathrm{rad}, \mathrm{w}-\mathrm{g}}$
$\mathrm{T}_{\mathrm{a}}$
$\mathrm{T}_{\mathrm{b}}$
$\mathrm{T}_{\mathrm{g}}$
$\mathrm{T}_{\mathrm{w}}$

\section{Nomenclatures}

Units

Evaporation heat transfer within the solar still from water mass and glass cover

Conduction heat transfer between basin liner and atmosphere

Radiation heat transfer between glass cover and sky from water mass and glass cover

Ambient Temperature

Basin liner Temperature

Glass cover Temperature

\section{Greek Letter Symbols:}

Symbols

$$
\begin{aligned}
& \alpha_{b} \\
& \alpha_{g} \\
& \alpha_{w}
\end{aligned}
$$

Nomenclatures

Basin liner absorptivity

Glass cover absorptivity

Water mass absorptivity
Units

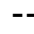

$-$ 


\section{REFERENCE}

1. K. Sampathkumar, T. V. Arjunan, P. Pitchandi, and P. Senthilkumar, "Active solar distillation-A detailed review," Renew. Sustain. Energy Rev., vol. 14, no. 6, pp. 15031526, 2010.

2. M. S. S. Abujazar, S. Fatihah, A. R. Rakmi, and M. Z. Shahrom, "The effects of design parameters on productivity performance of a solar still for seawater desalination: A review," Desalination, vol. 385, pp. 178-193, 2016.

3. H. M. Qiblawey and F. Banat, "Solar thermal desalination technologies," Desalination, vol. 220, no. 1-3, pp. 633-644, 2008.

4. A. El-Sebaii and E. El-Bialy, "Advanced designs of solar desalination systems: A review,” Renew. Sustain. Energy Rev., vol. 49, pp. 1198-1212, 2015.

5. H. N. Panchal, "Use of thermal energy storage materials for enhancement in distillate output of solar still: A review," Renew. Sustain. Energy Rev., vol. 61, pp. 86-96, 2016.

6. B. a Jubran, "Effect of climatic, design and operational parameters on the yield of a simple solar still Al-Hinai, H. et al. Energy Conversion and Management, 2002, 43, (13), 1639-1650," Fuel Energy Abstr., vol. 44, no. 2, p. 87, 2003.

7. H. N. Singh and G. N. Tiwari, "Monthly performance of passive and active solar stills for different Indian climatic conditions," Desalination, vol. 168, no. 1-3, pp. 145-150, 2004.

8. V. Velmurugan and K. Srithar, "Performance analysis of solar stills based on various factors affecting the productivity - A review," Renew. Sustain. Energy Rev., vol. 15, no. 2, pp. 1294-1304, 2011.

9. H. Ben Halima, N. Frikha, and R. Ben Slama, "Numerical investigation of a simple solar still coupled to a compression heat pump," Desalination, vol. 337, no. 1, pp. 60-66, 2014.

10. E. Kabeel, Z. M. Omara, and F. A. Essa, "Enhancement of modified solar still integrated with external condenser using nanofluids: An experimental approach," Energy Convers. Manag., vol. 78, pp. 493-498, 2014.

11. E. Kabeel, A. Khalil, Z. M. Omara, and M. M. Younes, "Theoretical and experimental parametric study of modi fi ed stepped solar still," vol. 289, pp. 12-20, 2012.

12. V. Velmurugan, K. J. Naveen Kumar, T. Noorul Haq, and K. Srithar, "Performance analysis in stepped solar still for effluent desalination," Energy, vol. 34, no. 9, pp. 11791186, 2009.

13. E. Kabeel, Z. M. Omara, and F. A. Essa, "Numerical investigation of modified solar still using nanofluids and external condenser," J. Taiwan Inst. Chem. Eng., vol. 75, no. April, pp. 77-86, 2017.

14. K. K. Murugavel, S. Sivakumar, J. R. Ahamed, K. K. S. K. Chockalingam, and K. Srithar, "Single basin double slope solar still with minimum basin depth and energy storing materials," Appl. Energy, vol. 87, no. 2, pp. 514-523, 2010.

15. Elango, N. Gunasekaran, and K. Sampathkumar, "Thermal models of solar still-A comprehensive review,” Renew. Sustain. Energy Rev., vol. 47, pp. 856-911, 2015. 